\title{
Study of Microstructure 304L Austenitic Stainless Steel Weld Deposited by GTAW for Root Pass and SMAW for Filler Passes
}

\author{
Harsimranjit Singh Randhawa ${ }^{1}$ and Sunil Kumar ${ }^{2}$ \\ ${ }^{1}$ PG Student, ${ }^{2}$ Assistant Professor, Department of Mechanical Engineering, \\ Yadavindra College of Engineering, Punjabi University Guru Kashi Campus, Talwandi Sabo Bathinda, Punjab, India \\ ${ }^{2}$ Corresponding Author E-Mail: sunilbaghla@yahoo.co.in
}

\begin{abstract}
In the present experimentation, a $10 \mathrm{~mm}$ thick austenitic stainless steel plate type $304 \mathrm{~L}$ is welded using single $\mathrm{V}$-joint configuration and approaching the joint from one side. Back purging has been employed to protect the rear side of the root pass weld metal against oxidation. The root pass has been deposited by gas tungsten arc welding (GTAW) process. The filler passes are deposited by shielding metal arc welding (SMAW) process at $90 \mathrm{~A}$ and $120 \mathrm{~A}$ welding currents giving heat inputs of the order of 0.679 and $0.933 \mathrm{~kJ} / \mathrm{mm}$ respectively while the speed of weld deposition was kept practically constant. The results of experimentation show that the microhardness of weld metal and heat affected zone (HAZ) of weldments produced at lower heat input is higher whereas impact toughness value of weld metal and HAZ is lower than that of joints produced at higher heat input. The microstructure of weld metal and heat affected zone developed at lower weld heat input has been observed finer in comparison to that resulted at higher heat input. This has primarily happened due to a higher rate of cooling at low heat input.
\end{abstract}

Keywords: Austenitic stainless steel 304L, GTAW, SMAW, weld heat input, back purging, weldment

\section{INTRODUCTION}

Austenitic stainless steel is a family of iron-chromiumnickel (Fe-Cr-Ni) alloy systems with low level of carbon. Higher values of nickel $(8-24 \%)$ are added to increase the ductility of the metal and higher values of chromium (16$26 \%$ ) enhances corrosion resistance [1]. Minimum $8 \%$ nickel is required to maintain austenitic (FCC) structure at all the temperatures [1]. Carbon steel on cooling transforms from austenite to a mixture of ferrite and cementite. The high chrome and nickel content of austenitic stainless steel suppress this transformation keeping the material fully austenite at all temperatures on cooling [2, 3]. Austenitic stainless steel includes AISI 200 and 300 series of which type 304 austenitic stainless steel is the most common [4]. The austenitic stainless steels are highly considered for use in mild and severe corrosive condition at temperatures that range from cryogenic temperatures, where they give high toughness, to elevated temperatures of nearly $600^{\circ} \mathrm{C}$, where they exhibit good oxidation resistance. They are used in beverage, food, pharmaceutical, petroleum, chemical process plants and architecture [4].

\section{RELATED WORK}

Choubey and Jatti (2014) [4] observed the effect of heat input controlled by welding current, arc voltage and welding speed on mechanical properties and microstructure of austenitic 202 type stainless steel weldments produced by SMAW. Authors found that the tensile strength decreases with the increase in heat input and tensile test fractured surfaces shows ductile and brittle failure.

David et al. (1995) [5] found that hot cracking can be prevented by small percentage of delta ferrite in austenitic stainless steel. On exposure to elevated temperatures for a long period of time, a continuous network of carbide forms at the austenite/ferrite interface which reduces the elevated temperature creep-rupture properties of austenitic stainless steel welds.

Tabish et al. (2014) [11] investigated the effect of heat input on the microstructure and mechanical properties of the GTA welded joint. The maximum tensile strength was reported with the weld joint produced by using low heat input. Micro-hardness at the upper surface of the weld was higher than that of near the center of the weld.

Korinko and Malene (2001) [6] have reported that solidification cracking and lack of penetration weld defects in austenitic stainless steel are attributed to the chemical composition of base and filler material. Authors concluded that in welding austenitic stainless steel, small amount of ferrite is to be retained in weld microstructure to reduce solidification cracking.

\section{EXPERIMENTATION}

\section{A. Samples for Experimentation}

In the present investigation, the $10 \mathrm{~mm}$ thick austenitic stainless steel plate grade AISI 304L has been used as a base material. The plates were butt welded selecting single $\mathrm{V}$ groove joint configuration with $65^{\circ}$ groove angle as shown in figure 1 . The root weld pass was deposited using $1.2 \mathrm{~mm}$ diameter austenitic stainless steel type 308L filler wire. The rest filler passes were deposited using $3.15 \mathrm{~mm}$ diameter type 308L-16 Rutile electrodes.

The chemical composition of base material, filler wire and electrode are also detailed in table 1. Before welding, plate shall be cleaned from external surface dirt, oil, grease or paint. The naturally forming chromium oxide layer, moisture and organic contaminants are also removed. 


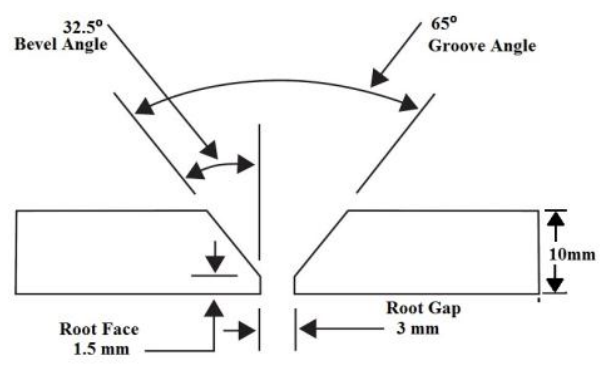

Fig. 1 V-groove butt weld joint [17]
An Inverter type power source USHA TIG 315P with constant current characteristic and a water cooled welding torch was used for GTAW welding of samples. The technical specification of the power source are Input: $3 \phi$ 400V, Welding current GTAW: 10-315(A), Welding current SMAW: 10-295(A), Duty cycle: 60\%, Arc ignition: High frequency, No load voltage: $45 \mathrm{~V}$, Gas pre flow: $0-2$ $(1 / \mathrm{s})$, Gas post flow: $0-10(1 / \mathrm{s})$.

TABLE I CHEMICAL COMPOSITION OF BASE AND FILLER MATERIAL [1]

\begin{tabular}{|l|c|c|c|c|c|c|c|}
\hline \multirow{2}{*}{ Material } & \multicolumn{7}{|c|}{ Chemical Composition (wt. \%) } \\
\cline { 2 - 9 } & $\mathbf{C r}$ & $\mathbf{N i}$ & $\mathbf{C}$ & $\mathbf{M n}$ & $\mathbf{S i}$ & $\mathbf{P}$ & $\mathbf{S}$ \\
\hline Base material 304L & 18.17 & 8.08 & 0.010 & 1.56 & 0.35 & 0.025 & 0.010 \\
\hline Wire 308L & 20.00 & 9.00 & 0.020 & 2.00 & 0.40 & 0.020 & 0.015 \\
\hline Electrode 308L-16 Rutile & 19.80 & 10.00 & 0.030 & 1.40 & 0.40 & - & - \\
\hline
\end{tabular}

\section{B. Specimen for Mechanical Tests}

The mechanical properties of the weldments were studied by testing tensile strength, impact toughness of the weld metal and heat affected zone, hardness profile of the joint and bend test of the welded assembly deposited on different heat inputs. The specimens were collected from the stable weld region by discarding the run-on and run-off portions of the weld. The specimen for tensile strength and impact toughness were prepared after machining the top and root reinforcement of the weld. Figure 2 shows the specimens machined to size confirming the relevant ASTM standard.
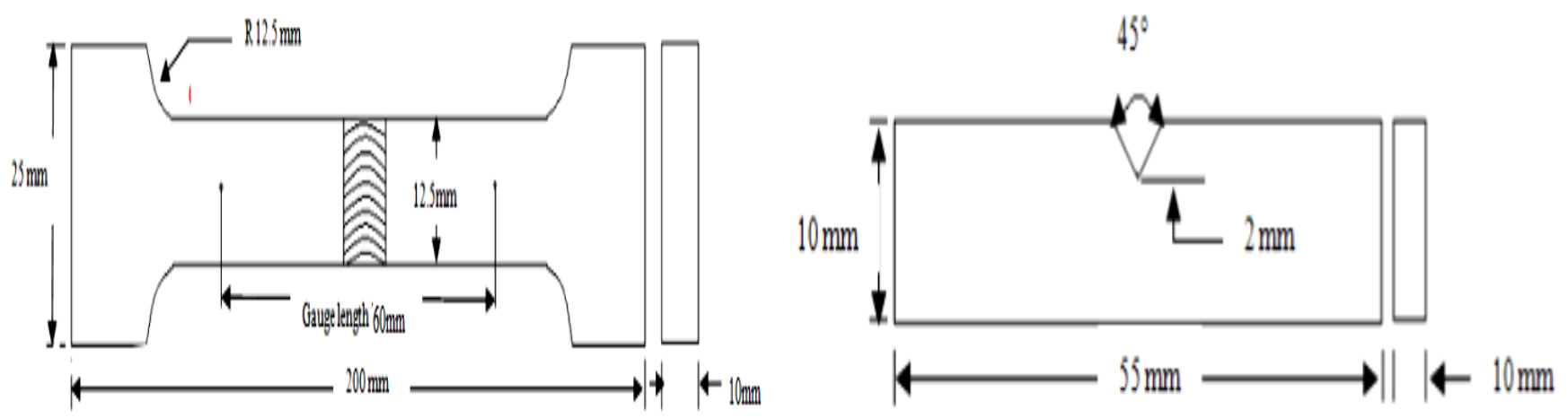

Fig. 2 Samples as per ASTM standards [1, 2, 3]

Optical metallographic examination was performed on the specimen to reveal the microstructure of weld metal, fusion line, heat affected zone (HAZ) and base metal of the joints produced at different heat inputs under the magnification of $100 \mathrm{X}$.

\section{Back purging fixture}

Figure 3 shows the fixture for back purging. It was constructed out of a $460 \times 260 \times 30 \mathrm{~mm}$ thick mild steel plate by machining a $25 \times 10 \mathrm{~mm}$ recess in the center of steel plate as shown in figure 2 to fix a $25 \times 10 \mathrm{~mm}$ thick grooved copper plate. The holes of $1.5 \mathrm{~mm}$ diameter with counter shank of $3 \mathrm{~mm}$ diameter were drilled at the center of grooved copper plate for purging of argon gas to protect the underside of root pass. One for argon gas inlet and other for argon gas out let with pressure control knob.

\section{Weld deposition}

The root pass was deposited by GTAW process using direct current electrode negative (DCEN) [straight polarity] for narrow and deep penetration. The root pass was deposited at 95A and 9V welding current and arc voltage respectively with average weld heat input of the order of $2.13 \mathrm{~kJ} / \mathrm{mm}$ giving full and complete root penetration in single pass. During deposition austenitic stainless steel 308L grade filler wire under the shielding of argon gas at the flow rate of 15 litre/min was used. The argon gas for back purging was supplied at the flow rate of $7.1 \mathrm{litre} / \mathrm{min}$. The welds were deposited with two different heat input combinations corresponding to different welding currents i.e. 90A (low heat input) and $120 \mathrm{~A}$ (high heat input) to reveal the influence of heat input on the microstructure. The welding parameters of weld deposited at 90A welding current are tabulated in table 2 . 


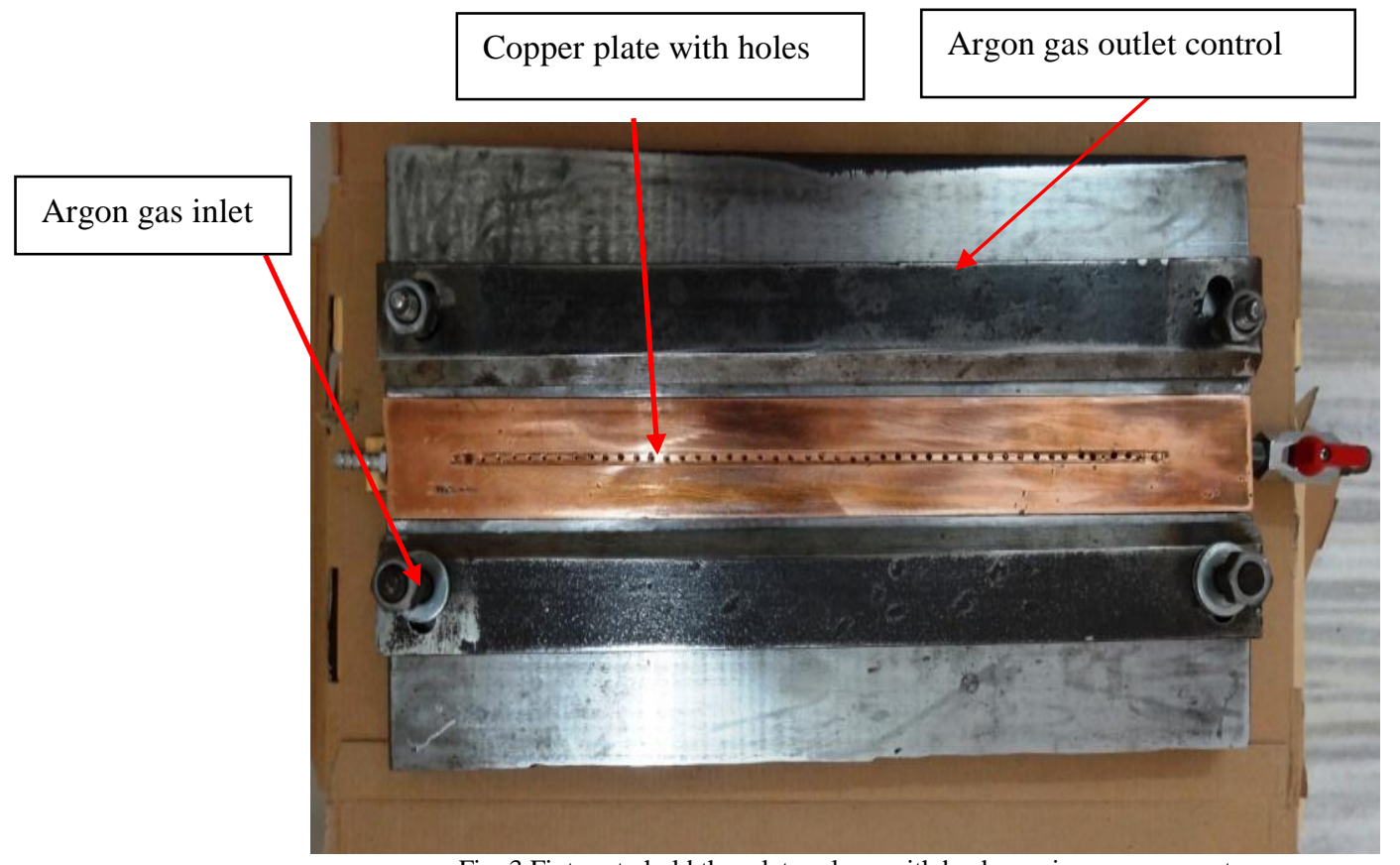

Fig. 3 Fixture to hold the plates along with back purging arrangement

TABLE II WELDING PARAMETERS AT 90A WELDING CURRENT

\begin{tabular}{|c|c|c|c|c|c|c|c|c|c|}
\hline $\begin{array}{c}\text { Weld } \\
\text { Layers }\end{array}$ & Passes & $\begin{array}{c}\text { Weld } \\
\text { Process }\end{array}$ & $\begin{array}{c}\text { Electrode/ } \\
\text { Wire Size } \\
(\mathbf{m m})\end{array}$ & $\begin{array}{c}\text { Current } \\
(\mathbf{A})\end{array}$ & $\begin{array}{c}\text { Voltage } \\
(\mathbf{V})\end{array}$ & Polarity & $\begin{array}{c}\text { Deposition } \\
\text { Speed } \\
\mathbf{m m} / \mathbf{s e c}(\mathbf{S})\end{array}$ & $\begin{array}{c}\text { Heat Input } \\
\mathbf{k J} / \mathbf{m m} \\
\boldsymbol{A} \times \boldsymbol{V}\end{array}$ & $\begin{array}{c}\text { Average } \\
\mathbf{H} \times \mathbf{I} \times \mathbf{1 0 0 0} \\
\mathbf{k J} / \mathbf{m m}\end{array}$ \\
\hline 1 & Root & GTAW & 1.6 & 95 & 9 & DCEN & 0.4 & 2.130 & 2.130 \\
\hline 2 & Filler & SMAW & 3.14 & 90 & 23 & DCEP & 3.0 & 0.690 & 0.771 \\
\hline 3 & Filler & SMAW & 3.14 & 90 & 23 & DCEP & 2.8 & 0.618 \\
\hline 4 & Filler & SMAW & 3.14 & 90 & 23 & DCEP & 3.2 & 0.679 \\
\hline 5 & Cap & SMAW & 3.14 & 90 & 23 & DCEP & 3.1 & 0.638 \\
\hline
\end{tabular}

The welding parameters of weld deposited at $120 \mathrm{~A}$ welding current are tabulated in table 3 . The average heat input for GTAW was resulted $2.13 \mathrm{~kJ} / \mathrm{mm}$ and for SMAW was $0.933 \mathrm{~kJ} / \mathrm{mm}$.

TABLE III WELDING PARAMETERS AT 120A WELDING CURRENT

\begin{tabular}{|c|c|c|c|c|c|c|c|c|c|}
\hline $\begin{array}{c}\text { Weld } \\
\text { Layers }\end{array}$ & Passes & $\begin{array}{c}\text { Weld } \\
\text { Process }\end{array}$ & $\begin{array}{c}\text { Electrode/Wire } \\
\text { Size } \\
(\mathbf{m m})\end{array}$ & $\begin{array}{c}\text { Current } \\
(\mathbf{A})\end{array}$ & $\begin{array}{c}\text { Voltage } \\
(\mathbf{V})\end{array}$ & Polarity & $\begin{array}{c}\text { Deposition } \\
\text { Speed } \\
\mathbf{m m} / \mathbf{s e c}(\mathbf{S})\end{array}$ & $\begin{array}{c}\text { Heat Input } \\
\mathbf{K J} / \mathbf{m m} \\
\boldsymbol{A} \times \boldsymbol{V} \\
\mathbf{S} \times \mathbf{1 0 0 0}\end{array}$ & $\begin{array}{c}\text { Average } \\
\mathbf{H e a t} \mathbf{I n p u t} \\
\mathbf{( k J / m m}\end{array}$ \\
\hline 1 & Root & GTAW & 1.6 & 95 & 9 & DCEP & 0.4 & 2.13 & 2.13 \\
\hline 2 & Filler & SMAW & 3.15 & 120 & 21 & DCEN & 2.8 & 0.9 & 0.85 \\
\hline 3 & Filler & SMAW & 3.15 & 120 & 22 & DCEN & 3.1 & 0.933 \\
\hline 4 & Cap & SMAW & 3.15 & 120 & 21 & DCEN & 2.4 & 1.05 & \\
\hline
\end{tabular}

\section{RESULTS AND DISCUSSIONS}

\section{A. Microstructure of base material}

The hot rolled austenitic stainless steel type 304L was used as a base material. The microstructure of base material consists of equiaxed austenite grains having approximately the same dimension in all directions. The microstructure of base material has been shown in figure 4 .

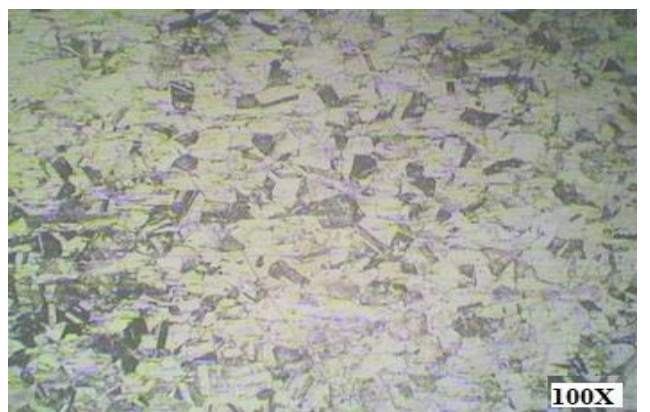

Fig. 4 Microstructure of the base material 


\section{B. Surface Appearance of Weld Deposit}

The surface appearance of top and root reinforcement of the weld deposited at $90 \mathrm{~A}$ and $120 \mathrm{~A}$ welding current are shown in figure 5 (a-d).

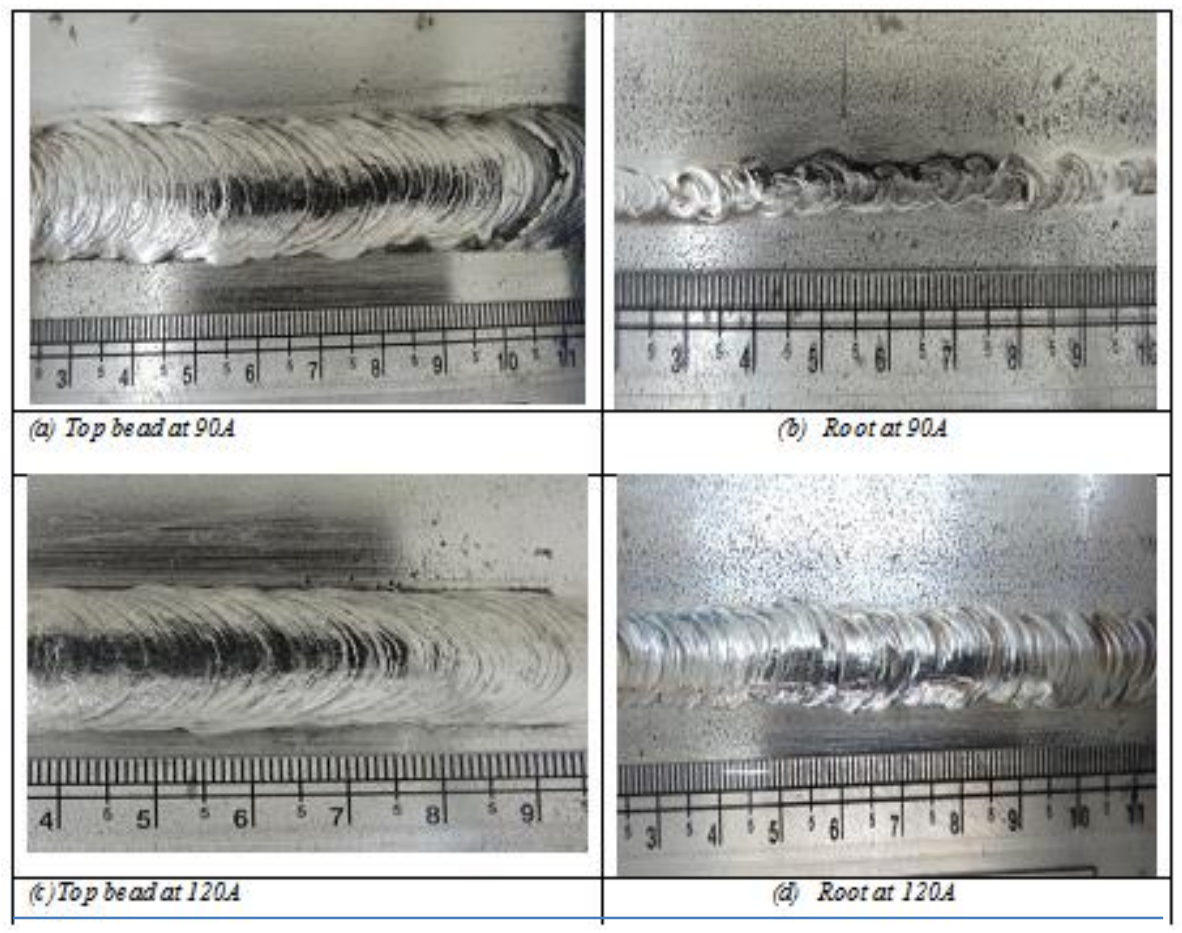

Fig. 5 Appearance of top bead and Root reinforcement at different welding currents

Figure 5 (a) and 5(c) depict the convex shaped bead with fine ripples and aesthetic look of the top reinforcement of weld deposited by SMAW at both the welding currents of $90 \mathrm{~A}$ and 120A. Figures 5(b) and 5(d) show penetration of the root pass deposited by GTAW. However root reinforcement deposited at $120 \mathrm{~A}$ is wider than that of deposited at 90A.

\section{Microstructure of weld metal}

The weld metal deposited either at $90 \mathrm{~A}$ or $120 \mathrm{~A}$ [shown in figure 6 \& 7] exhibit dendritic microstructure having primary growth in the direction of heat flow. The microstructure developed at 120A appears to be coarser in comparison that developed at 90A. The microstructure of weld metal developed at lower heat input of the order of $0.68 \mathrm{~kJ} / \mathrm{mm}(90 \mathrm{~A})$ reveals greater proportion of residual $\delta$ ferrite as shown in figure $6 \mathrm{a}$ in comparison to than that of developed at higher heat input of the order of $0.93 \mathrm{~kJ} / \mathrm{mm}$ $(120 \mathrm{~A})$ as shown in figure $6 \mathrm{~b}$. This can be attributed to higher cooling rate with the decrease of heat input giving lesser time for $\delta \rightarrow \gamma$ transformation and consequently greater proportion of $\delta$ ferrite is retained.

This is further explained that the microstructure of 304 austenitic stainless steel is mainly composed of austenite $(\gamma-$ $\mathrm{Fe}$ ) under the condition of equilibrium solidification. During non-equilibrium rapid solidification condition, the high cooling rate will result in incomplete $\delta \rightarrow \gamma$ transformation and some metastable $\delta$-Fe shall remain untransformed [3].

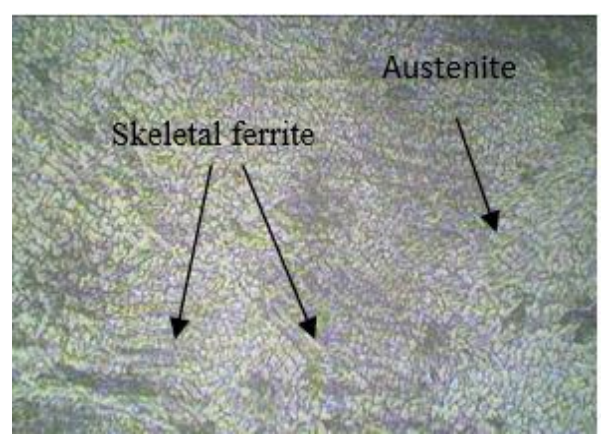

Fig. 6 Microstructures (100x) of weld metal at $90 \mathrm{~A}(0.68 \mathrm{~kJ} / \mathrm{mm})$

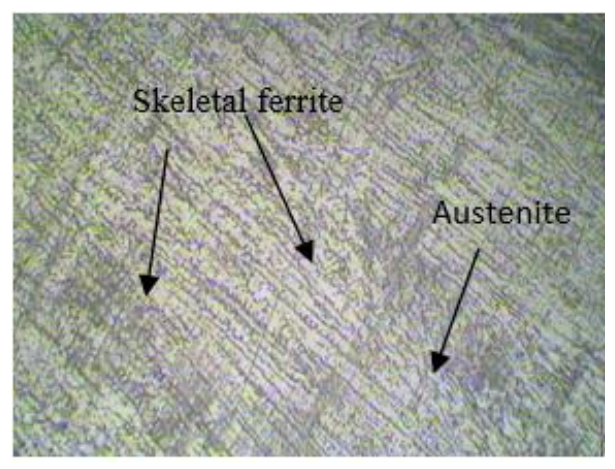

Fig. 7 Microstructures (100x) of weld metal at $120 \mathrm{~A}(0.93 \mathrm{~kJ} / \mathrm{mm})$ 


\section{Microstructure of heat affected zone (HAZ)}

The typical microstructures of heat affected zone (HAZ) developed at $90 \mathrm{~A}$ and $120 \mathrm{~A}$ welding current producing weld heat input of the order of 0.68 and $0.93 \mathrm{~kJ} / \mathrm{mm}$ are shown in figure 7 (a \& b). The morphology of weld metal and HAZ is clearly distinguishable in microstructure developed at both the welding currents. The dendrites of weld metal as depicted in figure $7 \mathrm{a}$ are comparatively finer produced at lower heat input of the order of $0.68 \mathrm{~kJ} / \mathrm{mm}$ than that of produced at $0.93 \mathrm{~kJ} / \mathrm{mm}$ as shown in figure $7 \mathrm{~b}$. This can be attributed to faster cooling rate at lower heat input gives lesser time at temperature for grain coarsening.

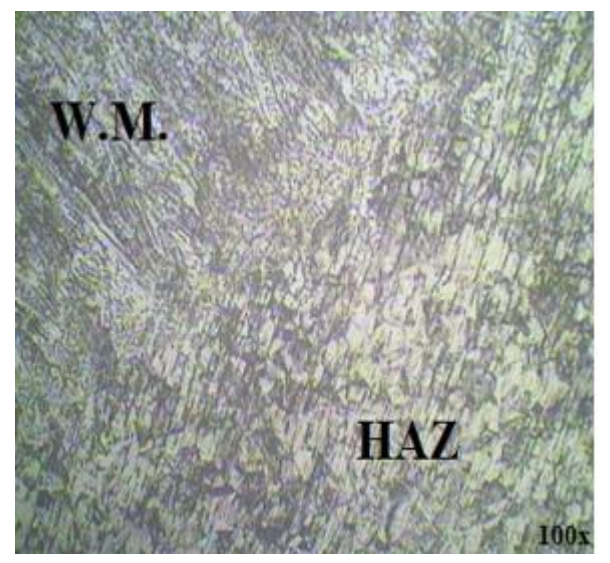

Fig. 8 Microstructures of heat-affected zone (HAZ) developed at 90A

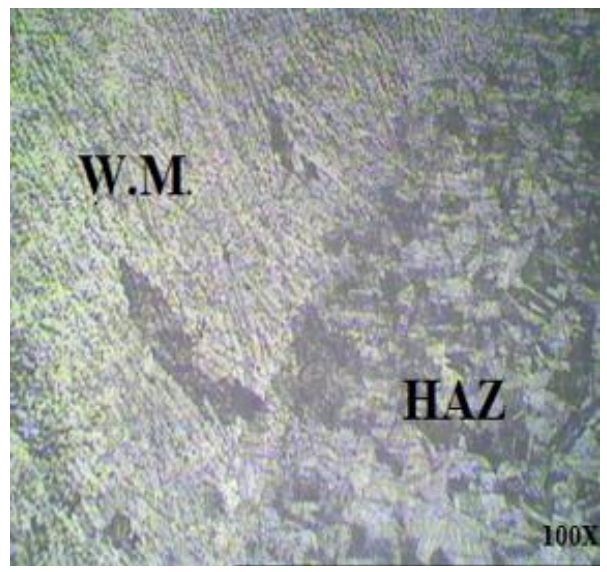

Fig. 9 Microstructures of heat-affected zone (HAZ) developed at 120A

The fusion line of the weldment produced at 120A welding current giving higher heat input of the order of $0.93 \mathrm{~kJ} / \mathrm{mm}$ and the grains in HAZ are visible coarsened in comparison to grain size of HAZ produced at 90 A welding current.

\section{CONCLUSIONS AND FUTURE SCOPE}

The heat affected zone (HAZ) of weldments produced at lower heat input is higher than that of joints produced at higher heat input. The microstructure of weld metal and heat affected zone developed at lower weld heat input has been observed finer in comparison to that resulted at higher heat input. Complete root penetration with back purging was successfully achieved with appropriate root reinforcement. Authors are working further to establish more elaborated results by incorporating micro hardness, bending strength, impact strength, toughness and brittle strength of the specimens.

\section{REFERENCES}

[1] American Society for Testing and Materials ASTM E8-15, "Standard Test Methods for Tension Testing of Metallic Materials".

[2] American Society for Testing and Materials ASTM E23-12, "Standard Test Methods for Notched Bar Impact Testing of Metallic Materials".

[3] American Society for testing and Materials ASTM E290-14, "Standard Test Methods for Bend Testing of Material for Ductility".

[4] A.Choubey and V.S.Jatti, "Influence of heat input on mechanical properties and microstructure of austenitic 202 grade stainless steel weldments", World Scientific and Engineering Academy and Society, Vol. 9, pp. 222-228, 2014.

[5] S.A. David, J.M. Vitek and D.J. Alexander, "Embrittlement of austenitic stainless steel welds", Scientific and Technical Information, Vol. 5, pp. 1-8, 1995.

[6] P.S. Korinko and S.H. Malene, "Consideration for the weldability of types 304L and 316L stainless steel", International American Society for Metals, Vol. 1, No. 4, pp. 61-68, 2001.

[7] K. Liu, Y. Li and J. Wang, "Microstructure and low temperature mechanical properties of 304 stainless steel joints by PAW+GTAW combined welding", Journal of Material Engineering and Performance, Vol. 25, pp. 4561-4573, 2016.

[8] C.E. Lyman, "Analytical electron microscopy of stainless steel weld metal on cooling, type 304L stainless steel weld metal transforms from delta ferrite to austenite by a massive transformation", The American Welding Society and the Welding Research Council, Vol. 34, pp.189-194, 1979.

[9] S. Nasser, W. Guo and D. P. Kihl, "Thermo-mechanical response of AL-6XN stainless steel over a wide range of strain rates and temperatures", Journal of the Mechanics and Physics of Solids, 49, pp.1823-1846, 2001.

[10] "Properties and Selection: Irons, Steels, and High Performance Alloys", ASM Handbook, International American Society for Metals, $10^{\text {th }}$ Ed., Vol. 1, pp.1394-1395, 1990.

[11] T.A. Tabish, T. Abbas, M. Farhan, S. Atiq and T.Z. Butt, "Effect of heat input on microstructure and mechanical properties of the TIG welded joints of AISI 304 stainless steel", International Journal of Scientific and Engineering Research, Vol. 5, pp. 1532-1541, 2014. 